\title{
SUSTAINABLE USE OF PLANTS FOR HEAVY METAL REMOVAL FROM WATER: PHYTOREMEDIATION
}

\author{
Akash P. Bhat ${ }^{1 *}$ and Pooja P. Bhat ${ }^{2}$ \\ ${ }^{1}$ Department of Chemical Engineering, Thadomal Shahani Engineering College, Bandra West, Mumbai 400050, Maharashtra, India, \\ ${ }^{2}$ Department of Botany, Ramnarain Ruia College, Matunga, Mumbai 400019, Maharashtra, India. \\ *Corresponding Author email: akashbhat1995@gmail.com
}

\begin{abstract}
There are various methods for removal of heavy metals from contaminated water and many of them can be costly and also consume a lot of resources. Phytoremediation is the use of plants as a filter for removal of unwanted elements and substances from contaminated water. This process is called rhizofiltration. Phytoremediation has not achieved a lot of importance on large scale level. This review- study shows how several species like Brassica juncea and Chenopodium amaranticolor, Pistia stratiotes, Helianthus annuus L. and Phaseolus vulgaris L. var. vulgaris, Eleocharis acicularis, Lemna minor L., Phragmites australis and Eichhornia Crassipes can be used for effective removal of heavy metals. These species are selected based on a review on various studies on rhizofiltration. Hence rhizofiltration can be an eco-friendly and innovative method of removal of heavy metals and has to be applied for large scale treatment of heavy metals in real time waters.
\end{abstract}

Keywords: Phytoremediation; Rhizofiltration; Plants; Heavy metals; Removal

\section{Introduction}

Heavy metals and pollutants in water and aqueous wastes are a huge threat currently to the environment. As it can be seen, a lot of high instrumentation technologies have been made in order to treat this water (Sourirajan, 1970; Blanchard et al., 1984; Kadirvelu et al., 2001; Zech and Sternad, 2007). The use of plants for specifically use in removal of pollutants cannot be traed back to a common source, but there are latest and current innovative and interesting technologies for such specific removal, called as phytoremediation.

Phytoremediation is defined as the use of green plants to remove pollutants from the environment or to render them harmless (Cunningham and Berti, 1993; Raskin et al., 1994). A lot of comprehensive research has been done on this topic. Use of different type of plants and their mechanism contribution for remediation of water is of interest here. Plants are known to sequester, degrade, and stimulate the degradation of organic contaminants in soil (Anderson et al., 1993; Shimp et al., 1993). Hence Phytoremediation should be givin much more importance to in India than it is currently given. More efficient environment friendly processes should be developed using phytoremediation. Pollutant free and pollution free processes should be at the utmost important place for combating global warming and pollution.

This novel plant-based technology can be divided and classified as per its uses. Pollutant accumulating plants can be used to remove metals or organics from the soil and concentrating them in parts. This is Phytoextraction (kumar et al., 1995). The use of plants can be done as a filter to remove pollutants from water and waste streams, this is known as Rhizofiltration (Dushenkov et al., 1995). Plants can also significantly degrade pollutants, this degradation being known as Phytodegradation (Newman and Reynolds, 2004). Similar reports can be seen for vast use of plants in phytostabilization and Phytovolatilization (Berti and Cunningham, 2000; Zayed et al., 2000). Many of this reviews or research on phytoremediation mainly concentrates on remediation of soil, this paper will vastly deal with possible purification of water. Rhizofiltration is an innovative low cost environment friendly method for remediation of water. Plant species belonging to Cruciferae (mustard, Thlaspi), Chenopodiaceae (Chenopodium, spinach), and Compositae (sunflower) have been shown to possess genetic potential to extract heavy metals from soil or water andaccu mulate them in plant parts (Koboi et al., 1986; Baker and Brooks, 1989). Other species showing these properties are Brassica juncea and Chenopodium amaranticolor (Eapen et al., 2003). All these plants or 
grasses are used to remove toxic metals such as $\mathrm{Cu}^{2+}, \mathrm{Cr}^{6+}$, $\mathrm{Ni}^{2+}, \mathrm{Pb}^{2+}$, andZn ${ }^{2+}$ from aqueous solutions (Dushenkov et al., 1997) by a process of rhizofiltration.

The current Review is about literature survey on the heavy metal removal from water using selective plant species. Following species were surveyed and noted. The species were selected based on their efficacy.

\section{Review on Rhizofiltration}

\section{Brassica juncea and Chenopodium amaranticolor}

Hairy roots induced at the site of infection were individually isolated and cultured on MS medium without any phytohormones, but supplemented with carbenicillin or cefotaxime at $500 \mathrm{mg} / \mathrm{L}$. The roots were further subcultured for another two passages on fresh MS medium, but with cefotaxime or carbenicillin reduced to $250 \mathrm{mg} \mathrm{L}^{-1}$ (Eapen et al., 2003; Murashige and Skoog, 1962), after the growth of hairy root cultures in MS basal medium for around 12 days, used uranyl chloride and for lower concentrations, four treatments were given at uranium concentrations of 25, 50, 100 , and $200 \mu \mathrm{M}$ for B. juncea roots and for Chenopodium roots, the uranium concentrations used were $25,50,100$, 250 , and $500 \mu \mathrm{M}$.

For higher concentrations, uranium concentrations of 500, 1000, 2000, 3000, and $5000 \mu \mathrm{M}$ were used. Estimation followed was by the method of Huang (Huang et al., 1998). The B. juncea hairy root tissue grown on MS medium with phosphate showed about $40 \%$ uptake of uranium against $97 \%$ of uranium uptake in MS devoid of phosphate. Hairy roots of B. juncea translocated $100 \%$ of the $1000 \mathrm{mM}$ uranium concentration to the roots, while $C$. amaranticolor was restricted to $500 \mathrm{mM}$ concentrations under similar conditions. For all concentrations used, $90 \%$ of the uranium was taken up by the root tissue within $10 \mathrm{~h}$ of treatment (Eapen et al., 2003)

\section{Indian mustard (Brassica juncea (L.) Czern.}

$B$. juncea roots were prepared and was treated by deionized water and then placed in lead solution for testing of $\mathrm{Pb}$ reduction. $\mathrm{Pb}$ concentration was checked using atomic spectrometer. Heavy metal to be removed in lead. The lowest concentration in the experimentation was $35 \mathrm{mg} / \mathrm{L}$ and the highest concentration tried was $500 \mathrm{mg} / \mathrm{L}$. These are quite different concentration ranges compared to the uranium range and it is because of lead accumulation found in water very commonly. Uranium concentrations are usually low unless special circumstances.

The $35 \mathrm{mg} / \mathrm{L}$ concentration after treatment was found to be negligible and beyond resolution. The final concentration after treatment for $500 \mathrm{mg} / \mathrm{L}$ concentration was found to be ranging from $17-18 \mathrm{mg} / \mathrm{L}$. Metal analysis was done by spectrometer by preparing root ash and Nitric acid and Hydrochloric acid. Bioaccumulation coefficient for lead was very good about 563. Colonial bent grass and kentucky bluegrass Agrostis tenuis Sibth. \& Poa pratensis L to be used $\mathrm{Pb}$ in roots was $169 \mathrm{mg} / \mathrm{g}$ compared to B. juncea $136 \mathrm{mg} / \mathrm{g}$. Concentrations below $150 \mathrm{mg} / \mathrm{g}$ of $\mathrm{Pb}$ did not show visible signs of toxicity for duration of the experiemnt. 300 and $500 \mathrm{mg}$ plants showed reduction in growth. Amount of metals accumulated in roots can exceed $10 \%$ of root DW. The process is biological surface absortin of nonlinear kinetics. Nothing about root to shoot export of accumulated metals (Dushenkov et al., 1995)

\section{Pistia stratiotes}

The heavy metals targeted in this study were Chromium and Cobalt. The metal concentration was measured with the help of atomic absorption spectrophotometer. $\mathrm{Cr}$ and $\mathrm{Co}$ from the water were very efficiently removed by Pistia stratiotes. It was clear that $\mathrm{Cr}$ was almost completely removed in 48 hours and non-detectible level was present after 72 hours.

Similar results were observed with the removal of Co from water. It could be seen clearly that almost all $\mathrm{Cr}$ is removed by Pistia stratiotes in 48 hours and there was negligible amount of $\mathrm{Cr}$ in water after 48 hours which cannot be detected. However, Co was not completely removed in 4 days. The main reason for this may be the toxicity of Co to Pistia stratiotes. $86 \%$ Co was removed while $100 \% \mathrm{Cr}$ was removed at the end of 4 days. The study was hence successful (Prajapati et al., 2012)

\section{Sunflower (Helianthus annuus L.) and Bean (Phaseolus vulgaris $L$. var. vulgaris).}

This study included the action of the above mentioned species in the rhizofiltration for removal of Uranium in contaminated water. Seeds were germinated and then cultivated hydroponically in a glass box with a $5 \mathrm{~cm}$ deep layer of silica beads ( $1 \mathrm{~mm}$ in diameter) until the buds came out (in the darkness for 4-7 days). The entire cultivation process was conducted for 2-3 weeks in a growth chamber at $25 \circ \mathrm{C}(80 \%$ relative humidity, $16 \mathrm{~h}$ of photoperiod/ day, and $0.05 \%$ of $\mathrm{CO}_{2}$ ) and $20 \mathrm{~g}$ of each plant cultivar was selected for rhizofiltration. Initial concentrations of 30, 80, 136, $287 \mu \mathrm{g} / \mathrm{L}$ Uranium for sunflower and 30, 80, 116 and $375 \mu \mathrm{g} / \mathrm{L}$ of Uranium for bean was taken for studies.

Sunflower removed more than $80 \%$ of the uranium from groundwater (30 $\mathrm{g} / \mathrm{L}$ of uranium) and the uranium concentration of the residual solution was maintained at about 6-7 $\mu \mathrm{g} / \mathrm{L}$. For the solution having $80 \mu \mathrm{g} / \mathrm{L}$ of uranium, the uranium removal efficiency reached more than $89 \%$ within $24 \mathrm{~h}$ of rhizofiltration. For bean, more than $70 \%$ of the uranium was removed from the solution $(30 \mu \mathrm{g} / \mathrm{L}$ of uranium) and the uranium concentration in the groundwater was reduced to $10 \mu \mathrm{g} / \mathrm{L}$ in $24 \mathrm{~h}$. As the initial concentrations of uranium in groundwater were 80 and $116 \mu \mathrm{g} / \mathrm{L}$, the uranium removal efficiencies exceeded $80 \%$. However, with high uranium concentrations of groundwater (375 and $646 \mu \mathrm{g} / \mathrm{L})$, the removal efficiency of rhizofiltration was 
reduced to approximately $60 \%$ and the uranium concentrations in treated water were 120 and $256 \mu \mathrm{g} / \mathrm{L}$, respectively. This specie was also successful in rhizofiltration but only for Uranium (Lee and Yang, 2010)

\section{Eleocharis acicularis}

Copper, Zinc, Arsenic, Cadmium and Lead were the controls in this study. This study was done in real time water in river in japan and hence has the effect of the above mentioned species on all the above mentioned heavy metals that were found in the said river. Eleocharis acicularis was cultivated in that local river. Metals concentrations in water were determined using inductively coupled plasma-mass spectrometry. Realtime water samples were used in this study. In the samples of river water, the abundance of heavy metals and arsenic (mg/L) decreases in the order $\mathrm{Zn}(1700$ $\pm 217), \mathrm{Cu}(114 \pm 37.7)$, As (38.1 \pm 5.35$)$, Cd (17.5 \pm 2.37$)$, $\mathrm{Pb}(0.274 \pm 0.040)$.

The maximum accumulations of $\mathrm{Cu}, \mathrm{Zn}, \mathrm{As}, \mathrm{Cd}$, and $\mathrm{Pb}$ in the shoots were higher than the initial concentrations by factors of 2040, 2940, 1530, 1200, and 17, respectively. The highest concentrations (mg/kg DW) of Zn (11 200), Cu (20 200), As (1470), and Cd (239) in the plant shoots were higher than the threshold values in defining a hyperaccumulator of $\mathrm{Zn}(10000), \mathrm{Cu}$ and $\mathrm{As}$ (1000), and Cd (100) [30], regardless of the cultivation point. E. acicularis shows BCFs for $\mathrm{Cu}, \mathrm{Zn}, \mathrm{As}, \mathrm{Cd}$, and $\mathrm{Pb}$ as large as 28.0, 8.0, 7.4, 11.8, and 1.7, respectively (Sakakibara $e t$ al., 2011). Since the methodology of this study is quite different from those above mentioned, this cannot be a good measure for comparison of efficacy of this species in effective rhizofiltration, but this paper shows the effective remediation of various heavy metals in real time contaminated water and soil samples and hence is important in our study.

\section{Eichhornia Crassipes}

Eichhornia Crassipes is commonly called Water Hyacinth. Various sampling stations were made in wetlands as realtime samples. At each sampling station, surface water, sediment, and water hyacinth plants were sampled. The concentrations of $\mathrm{Cu}, \mathrm{Cd}, \mathrm{Ni}, \mathrm{Pb}$, and $\mathrm{Zn}$ were analyzed by ICP-AES (ICP LIBERTY) with an ultrasonic nebulizer. The minimum detection limits were found to be $1.3,1.2$, $2.4,3.2$, and $1.3, \mu \mathrm{g} / \mathrm{kg}$, respectively.

For Cadmium, When the external concentration reached the maximum of $0.06 \mathrm{mg} / \mathrm{L}$, the maximum accumulation in the roots was $10.05 \mathrm{mg} \mathrm{kg}^{-1} \mathrm{dw}$. The accumulation of $\mathrm{Cu}$ was $1,110 \mathrm{mg} \mathrm{kg}^{-1} \mathrm{dw}$. This amount was the highest level as compared to other four trace elements accumulated in the plant roots. The $\mathrm{Cu}$ concentration in roots was about 7 to 24 times higher than in shoots. Although the concentration of $\mathrm{Ni}$ exceeds $\mathrm{Zn}$ in the water environment, the absorption of $\mathrm{Ni}$ in the shoots was less than that of $\mathrm{Zn}$. The amount of $\mathrm{Pb}$ accumulated in the roots was about 4 to 16 times higher than that in the shoots. When the $\mathrm{Pb}$ concentration was lowest at $0.03 \mathrm{mg} / \mathrm{L}$, the BCF in the shoots and roots was highest, at 555 and 4,333, respectively. $\mathrm{Cd}, \mathrm{Cu}, \mathrm{Ni}, \mathrm{Pb}$, and $\mathrm{Zn}$ were associated with large BCF at low concentrations.

As regard with the $\mathrm{BCFs}$, water hyacinth is effective to absorb and accumulate trace elements in plant roots only for $\mathrm{Cu}$ from sediment. Furthermore, the BCF for $\mathrm{Pb}$ reveals partial e low concentrations in the sediment. Other elements such as $\mathrm{Cd}, \mathrm{Ni}$, and $\mathrm{Zn}$ are less effectively bioconcentrated as the corresponding BCF values were less than 100 (Liao and Chang, 2004).

\section{Lemna minor $L$.}

Phytoremediation using species L. minor for cadmium, copper, lead, and nickel from two types of effluent in crude or raw form was elucidated in an experiment using hydroponic studies for a period of 31 days. Heavy metals concentration in water and plant sample were analysed at various days. Removal efficiency, metal uptake and bioconcentration factor were also calculated by Bokhari. Effluent Characterization was done for both the raw samples for analysing and it showed that municipal effluent (ME) was highly contaminated in terms of nutrient and organic load than sewage mixed industrial effluent (SMIE).

Plant samples were washed three times with distilled water, oven-dried at $70^{\circ} \mathrm{C}$ till constant weight, milled and sieved to $<1 \mathrm{~mm}$. Plant material $(0.25 \mathrm{~g})$ was digested with $10 \mathrm{ml}$ of double acid $\left(\mathrm{HNO}_{3}-\mathrm{HClO}_{4}\right.$ in the ratio of $2: 1$ respectively) on hot plate (Type 2200 Hot Plate) by slowly raising the temperature. The digested sample was diluted to $50 \mathrm{ml}$ with de-ionized water and filtered through what man no. 42 filter paper. Periodically collected water samples were filtered immediately after collection by using $0.45 \mu \mathrm{m}$ membrane filter through vacuum filtration apparatus and preserve/acidify with $\mathrm{HNO}_{3}$. Determination of heavy metal $(\mathrm{Cd}, \mathrm{Cr} \mathrm{Cu}, \mathrm{Pb}$ and $\mathrm{Ni}$ ) contents in plant and water samples were carried out by graphite furnace Atomic Absorption Spectrometer. Results confirmed the accumulation of heavy metals within plant and subsequent decrease in the effluents. Removal efficiency was greater than $80 \%$ for all metals and maximum removal was observed for nickel $(99 \%)$ from SMIE. Accumulation and uptake of lead in dry biomass was significantly higher than other metals. Bioconcentration factors were less than 1000 and maximum BCFs were found for copper (558) and lead (523.1) indicated that plant is a moderate accumulator of both metals. Overall, L. minor showed better performance from SMIE and was more effective in extracting lead than other metals (Bokhari et al., 2016).

\section{Common Reed (Phragmites australis)}

The effectiveness of Common Reed for phytoremediation of heavy metals from municipal waste leachate was investigated. The plants were transplanted into pots containing $10 \mathrm{~L}$ of mixed urban waste leachate and water 
(mixed 80 percentages of waste leachate with $20 \%$ of water; V: V) and aerated during experiments. Central composite design (CCD) and response surface methodology (RSM) were used in order to clarify the nature of the response surface in the experimental design and explain the optimal conditions of the independent variables. In the optimum conditions, the amount of removed $\mathrm{Fe}, \mathrm{Mn}, \mathrm{Cu}$, and $\mathrm{Ni}$ were $25.049,9.623,6.112$, and $0.900 \mathrm{mg} / \mathrm{kg}$. This shows that even common reed can be effective in some amount of phytoremediation. (Mojiri et al., 2015)

\section{Conclusion}

As we can see, Brassica juncea and Chenopodium amaranticolor, Pistia stratiotes, Helianthus annuus L. and Phaseolus vulgaris L. var. vulgaris, Eleocharis acicularis, Lemna minor L., Phragmites australis and Eichhornia Crassipes have been discussed for effective removal of several heavy metals from water. At various places, Heavy metal composition in contaminated water is a big problem. There are various solutions for removal of these heavy metals but can be expensive, may consume technology. Plants are an eco-friendly method for treatment of contaminated water. A proper system has to be developed for a proper process through which real-time water samples can be treated. Water Hyacinth and Eleocharis acicularis is a good option for rhizofiltration. The proposed method could include building of rhizofiltration farms for heavy metal removal from water. These farms can contain properly cultured plants capable of rhizofiltration considering the concentration and composition of contaminants in water. Any method of extraction of absorbed heavy metals from the plants can be studied. Phytoremediation and rhizofiltration are an effective and environment friendly method for filtration of heavy metals. All possible species of plants can be studied for their role in efficacy for removal of heavy metals from water.

Hence, Phytoremediation should be given much more importance to in India than it is currently given. More efficient environment friendly processes should be developed using phytoremediation. Pollutant free and pollution free processes should be at the utmost important place for combating global warming and pollution. This review concludes that some of the species studied are hereby mentioned and are the best possible plant species for rhizofiltration.

\section{Acknowledgements}

Akash would like to acknowledge Professors from Thadomal Shahani Engineering College for resources and help.

\section{References}

Anderson TA, Guthrie EA and Walton BT (1993) Bioremediation in the rhizosphere. Environmental Science \& Technology 27(13): 2630-2636. DOI: 10.1021/es00049a001
Baker AJMN and Brooks RR (1989) Terrestrial higher plants which hyperaccumulate metal elements - a review of their distribution, ecology and phytochemistry Biorecovery 1: 81-126.

Berti WR and Cunningham SD (2000), Phytostabilization of metals.Phytoremediation of toxic metals: using plants to clean-up the environment. New York, John Wiley \& Sons, Inc, 71-88.

Blanchard G, Maunaye M and Martin G (1984), Removal of heavy metals from waters by means of natural zeolites. Water Research 18(12): 1501-1507. DOI: 10.1016/00431354(84)90124-6

Bokhari SH, Ahmad I, Mahmood-Ul-Hassan M and Mohammad A (2016). Phytoremediation potential of Lemna minor L. for heavy metals. International journal of phytoremediation, 18(1): 25-32. DOI: 10.1080/15226514.2015.1058331

Cunningham SD and Berti WR. (1993), Remediation of contaminated soils with green plants: an overview. In Vitro Cell. Dev. Biol. 29: 207-12. DOI: 10.1007/BF02632036

Dushenkov S, Vasudev DD, Kapulnik Y, Gleba D, Fleisher D, Ting KC and Ensley B (1997), Removal of uranium from water using terrestrial plants. Environ. Sci. Technol. 31: 3468-3474. DOI: 10.1021/es9702201

Dushenkov V, Kumar PN, Motto H and Raskin I (1995), Rhizofiltration: the use of plants to remove heavy metals from aqueous streams. Environmental science \& technology 29(5): 1239-1245. DOI: 10.1021/es00005a015

Eapen S, Suseelan, KN, Tivarekar S, Kotwal SA and Mitra R (2003), Potential for rhizofiltration of uranium using hairy root cultures of Brassica juncea and Chenopodium amaranticolor. Environmental research 91(2): 127-133. DOI: 10.1016/S0013-9351(02)00018-X

Huang NE, Shen Z, Long SR, Wu MC, Shih H H, Zheng QZ, NaiChyuan Y, Chi CT and Liu HH (1998), The empirical mode decomposition and the Hilbert spectrum for nonlinear and non-stationary time series analysis. In Proceedings of the Royal Society of London A: Mathematical, Physical and Engineering Sciences 454(1971): 903-995. DOI: 10.1098/rspa.1998.0193

Kadirvelu K, Thamaraiselvi K and Namasivayam, C (2001), Removal of heavy metals from industrial wastewaters by adsorption onto activated carbon prepared from an agricultural solid waste. Bioresource Technology 76(1): 63-65. DOI: 10.1016/S0960-8524(00)00072-9

Koboi T, Noguchi A and Yazaki J, (1986), Family dependent cadmium accumulation characteristics in higher plants. Plant \& Soil 92: 405-415. DOI: 10.1007/BF02372488

Kumar P.N, Dushenkov V, Motto H and Raskin I (1995), Phytoextraction: the use of plants to remove heavy metals from soils. Environmental Science \& Technology 29(5): 1232-1238. DOI: 10.1021/es00005a014

Lee M and Yang M (2010), Rhizofiltration using sunflower (Helianthus annuus L.) and bean (Phaseolus vulgaris L. 
var. vulgaris) to remediate uranium contaminated groundwater. Journal of hazardous materials 173(1): 589596. DOI: 10.1016/j.jhazmat.2009.08.127

Liao SW and Chang WL (2004), Heavy metal phytoremediation by water hyacinth at constructed wetlands in Taiwan. Photogramm. Eng. Remote Sensing 54: 177-185.

Mojiri A, Aziz HA, Tajuddin RBM, Gavanji S and Gholami A (2015). Heavy Metals Phytoremediation from Urban Waste Leachate by the Common Reed (Phragmites australis). In Phytoremediation, Springer International Publishing, 75-81. DOI: 10.1007/978-3-319-10969-5_7

Murashige T and Skoog F (1962). A revised medium for rapid growth and bio assays with tobacco tissue cultures. Physiologia plantarum, 15(3): 473-497. DOI: 10.1111/j.1399-3054.1962.tb08052.x

Newman LA and Reynolds CM (2004), Phytodegradation of organic compounds. Current Opinion in Biotechnology 15(3): 225-230. DOI: 10.1016/j.copbio.2004.04.006

Prajapati SK, Meravi N and Singh S (2012), Phytoremediation of Chromium and Cobalt using Pistia stratiotes: A sustainable approach. Proceedings of the International Academy of Ecology and Environmental Sciences 2(2): 136.
Raskin I, Kumar PBAN, Dushenkov S and Salt DE. (1994), Bioconcentration of heavy metals by plants. Curr. Opin. Biotechnol. 5: 285-90. DOI: 10.1016/09581669(94)90030-2

Sakakibara M, Ohmori Y, Ha NTH, Sano S and Sera K (2011), Phytoremediation of heavy metal-contaminated water and sediment by Eleocharis acicularis. CLEAN-Soil, Air, Water 39(8): 735-741. DOI: 10.1002/clen.201000488

Shimp JF, Tracy JC, Davis LC, Lee E, Huang W, Erickson LE and Schnoor JL (1993), Beneficial effects of plants in the remediation of soil and groundwater contaminated with organic materials. Critical Reviews in Environmental Science and Technology 23(1): 41-77. DOI: 10.1080/10643389309388441

Sourirajan S (1970), Reverse osmosis. London, UK: Logos Press Ltd.

Zayed A, Pilon-Smits E, De Souza M, Lin Z Q and Terry N (2000), Remediation of selenium-polluted soils and waters by phytovolatilization. Phytoremediation of contaminated soil and water, 61-83.

Zech T and Sternad W (2007), Membrane filtration-based wastewater treatment. Chemical TechnologyBedfordview- 21. 